\title{
«ЧЕРНЫЕ», «ВНУТРЕННИЕ» И «СЕРЕБРЯНЫЕ» БОЛГАРЫ (СЕМАНТИКА И ГЕНЕЗИС ЭТНОНИМОВ)
}

\author{
О. Б. Бубенок
}

Бубенок О. Б. «Чорні», «внутрішні» та «срібні» болгари (семантика та генеза етнонімів). У середньовічних письмових джерелах, де описана етнічна ситуація у степах Східної Свропи середини X-XII ст., фігурують незрозумілі назви болгар - «чорні», «внутрішні» та «срібні». Одні дослідники вважають, що ці етнічні терміни семантично були пов'язані між собою. Інші ж учені, навпаки, не бачать між ними зв’язку. Унаслідок проведеного аналізу вдалося встановити, що термін «чорні болгари» означав болгар Північного Приазов'я і міг мати семантичні значення - «головні» або «справжні» болгари. Словосполучення «внутрішні болгари» могло означати болгар степів Подоння і Приазов’я й мало відношення до лівого (західного) крила первинного об'єднання кочових болгар. Що ж до «срібних» болгар, то це було позначення для болгар Східного Приазов'я і Середнього Поволжя та мало семантичне значення «заможні». Як бачимо, назви для болгарських племен Східної Свропи не були між собою пов'язані семантично. Це можна пояснити тим, що згадані етнічні терміни дійшли до нас із різних письмових джерел.

Ключові слова: «чорні», «внутрішні» та «срібні» болгари; Костянтин Багрянородний; «Повість минулих літ»; «Худуд ал-‘Алам»; Іаков Мніх; Іпатіївський літопис; етнонім; семантика; походження.

Бубенок О. Б. «Черные», «внутренние» и «серебряные» болгары (семантика и генезис этнонимов). В средневековых письменных источниках, где описана этническая ситуация в степях Восточной Европы в середине X-XII вв., фигурируют непонятные названия болгар - «черные», «внутренние» и «серебряные». Одни исследователи считают, что эти этнические термины семантически были связаны между собой. Другие же ученые, наоборот, не видят между ними связи. В результате проведенного анализа удалось установить, что термин «черные болгары» обозначал болгар Северного Приазовья и мог иметь семантические значения - «главные» или «настоящие» болгары. Словосочетание «внутренние болгары» могло обозначать болгар степей Подонья и Приазовья и имело отношение к левому (западному) крылу первоначального объединения кочевых болгар. Что же касается «серебряных» болгар, то это было обозначение для болгар Восточного Приазовья и Среднего Поволжья и имело семантическое значение «богатые». Как видим, названия для болгарских племен Восточной Европы не были между собою связаны семантически. Это можно объяснить тем, что упомянутые этнические термины дошли до нас из различных письменных источников.

Ключевые слова: «черные», «внутренние» и «серебряные» болгары; Константин Багрянородный; «Повесть временных лет»; «Худуд ал-“Алам»; Иаков Мних; Ипатьевская летопись; этноним; семантика; происхождение.

Bubenok O. B. "Black", "Inner" and "Silver" Bulgarians (Semantics and Genesis of Ethnic Names). In medieval writing sources, where an ethnic situation in the steppes of Eastern Europe in the middle of 10th-12th centuries AD is described, the incomprehensible names of the Bulgarians ("Black", "Inner" and "Silver") had appeared. Some researchers considered that these ethnic terms were connected semantically. Others do not see the connection between its. As a result of the conducted analysis it was succeeded to set, that term the "Black Bulgarians" designated the Bulgarians of North Azov Sea coast and it could have semantic values - "Main" or "Natural" Bulgarians. Word-combination "Inner Bulgarians" could mean the Bulgarians of the steppes of Don basin and Azov Sea coast and also it related to the left (western) wing of the primary union of the nomadic Bulgarians. The "Silver Bulgarians" was a denotation for the Bulgarians of East Azov Sea coast and Middle Volga basin and it had a semantic value "Rich". So, these names for the Bulgarian tribes of Eastern Europe were not connected semantically. It can be explained to those, that these ethnic terms came to us from the different writing sources.

Keywords: "Black", "Inner" and "Silver" Bulgarians; Constantine Porphirogenitus; "The Tale of Bygone Years"; "Hudud al-“Alam”; Jacob Mnikh; Ipatievskaya chronicle; ethnic name; semantics; origin.

В средневековых письменных источниках, где описана этническая ситуация в степях Восточной Европы в середине X-XII вв., фигурируют некоторые названия болгар, происхождение и семантика которых вызывают среди исследователей острую дискуссию. Речь идет о так называемых «черных», «внутренних» и «серебряных» болгарах. С одной стороны, наблюдается стремление видеть в них или одно подразделение болгар, или тен- 
денция сводить все эти названия в единую семантическую плоскость. С другой стороны, некоторые исследователи отрицают какую-либо прямую связь между носителями данных этнических названий и, соответственно, считают их отдельными племенными подразделениями восточноевропейских болгар. При этом нет единогласия в вопросах локализации упомянутых групп болгар, а также в объяснении значений их названий. Естественно, чтобы разобраться в данной проблеме, необходимо обратиться к источникам.

Так, наиболее известным считается этнический термин «черные болгары». Константин Багрянородный в главе 12 своего трактата «Об управлении империей» отмечал: «[Знай], что так называемая Черная Булгария может воевать с хазарами» ${ }^{2}$. Второе же упоминание о Черной Булгарии содержится в 42 главе трактата: «В это Меотидское озеро впадает много больших рек; в северной стороне от него река Днепр, от которой росы продвигаются и в Черную Булгарию, и в Хазарию, и в Мордию»². Таким образом, из сообщения Константина получается, что Черная Булгария находилась в степях между нижним течением Днепра и владениями хазар.

Примерно такую же картину дает «Повесть временных лет». В приведенном там тексте договора киевского князя Игоря с Византией от 945 г. сказано: «а w сихъ wжє то прихо,А,Ать

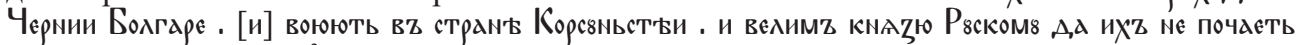
. в пакость стран' єго» ${ }^{3}$. Данное сообщение позволяет считать, что владения черных болгар находились вблизи Крымского полуострова, на который они могли вторгаться либо через Керченский пролив, либо через Перекоп. Сложность локализации черных болгар состоит в том, что до сих пор мы точно не знаем, где проходила западная граница Хазарского каганата в середине X в. Отсюда возникают проблемы идентификации черных болгар с теми группами болгар, о которых упоминают другие письменные источники.

Одной из таких загадочных групп являются так называемые «внутренние болгары». Считаются, что основные сведения о них содержатся в фарсоязычном географическом трактате конца X в. «Худуд ал-“Алам». Неизвестный мусульманский автор упоминает о них несколько раз. Так, впервые «внутренние болгары» появляются в начале трактата, где идет описание морей. Автор трактата отмечает, что северные пределы Черного моря (Pontos) занимают «печенеги (Bajanāk), хазары (Khazār), мирваты (Mirvāt), внутренние булгары (Bulghār-i dākhil) и сакалибы (Saqlāb)»" .

В разделе, посвященном горам, автор «Худуд ал-'Алам» описывает горы, якобы находившиеся между «внутренними» болгарами и русью: «затем они достигают страны хазарских печенегов и разделяют внутренних булгар от руси (miyān-i Bulghār-i dārkhil [va*] Urūs biburradh)» ${ }^{5}$. После этого владения «внутренних» болгар были упомянуты в списке стран, где они оказались в одной группе с территориями, которые населяли следующие народы: «сакалиба (Saqlāb), хазарские печенеги (Bajanāk-i Khazār), мирваты (Mirvāt), внутренние болгары (Bulghār-i dākhil), Русь (rūs)...» ${ }^{6}$. Далее «внутренние» болгары упоминаются при описании страны сакалибов: «На восток от этой страны находятся внутренние булгары (Bulghār-i andarūni) и некоторые из русов; на юг от нее расположена некоторая часть моря Гурз (Черного - О. Б.) и некоторая часть Рума (Византии - О. Б.); на запад и север от нее - незаселенные пространства Севера» ${ }^{7}$.

И, конечно же, наиболее подробная информация содержится в разделе, посвященном описанию страны «внутренних булгар» (Bulghār-i dākhil): «На восток от нее находится Мирват (Mirvāt); на юг от нее расположено море Гурз; на западе проживают сакалибы (Saqlāb); на север от нее расположены горы Рус. Это страна без городов. Жители храбры, воинственны и внушают страх. Их нравы походят на нравы тех тюрок, которые живут по соседству со страной хазар. Со всеми русами у них война; со всеми окрестными областями они ведут торговлю. Они владеют баранами, оружием и приспособлениями для войны» ${ }^{8}$. Далее «внутренние» болгары сразу же упомянуты при описании страны мирватов: «На восток от нее находятся какие-то горы и некоторые из хазарских печенегов; на юг от нее некоторые из хазарских печенегов и море Гурз; на запад далее находятся некоторые части моря Гурз и внутренние булгары; на север немного далее расположены горы В.н.н.д.р» ${ }^{9}$. Далее в тексте «Худуд ал-“Алам» «внутренние» болгары больше не упоминаются.

Как видим, главными ориентирами для локализации «внутренних» булгар являются загадочные «мирваты», так называемые «хазарские печенеги», Русь и море «Гурз». Таким образом, разобравшись в локализации «внутренних» булгар, можно попытаться опре- 
делить их происхождение и то, как они соотносятся с другими группами булгар юга Восточной Европы.

Не менее интересна и третья группа булгар - «серебряные». До сих пор предметом дискуссии остается происхождение названия «серебряные болгары», упомянутого лишь в двух средневековых текстах. Так, в первый раз оно было отмечено во фрагменте агиографического сочинения Иакова Мниха «Память и похвала князю русскому Владимиру», написанного в конце XI в. Там говорится о походах киевского князя Владимира за несколько лет до 988 г.: «Тако же пребывающю князю Володимерю в добрых делех, благодать божия просвещаше сердце его, и рука господня помагаше ему. И побежаше вся врагы своя, бохутся его вси. Идеже идяше, одолеваше Радимици победи и дань на них положи, Вятичи победи и дань на них положи на обоих, и Ятьвягы взя, и сребныя Болгары победи, и на Казары шед, победи я и дань на них положи. Умысли же и на Гречки и град Корсунь...» ${ }^{10}$.

Во второй раз «серебряные болгары» фигурируют в той части Ипатьевской летописи, где речь идет о походе Руси на Волжскую Булгарию в 1183 г.: «... бъс идоущимъ по Волзе на Болгары . поидоша на место идеже островъ нарецаємыи . Исади . оустьє Цевце выседъ на брегъ . и тоу оставиша все носадъ . и галее . и Белозерьскии полкъ остави же оу нихъ . воєводоу Фомоу Назаковича . а дроугого Дорожае . то бо бяшь ємоу от нь слоуга инъе воєводъ оставиша . и князи когождо оу своихъ людии . сами же поидоша на конехъ землю Болгарьскоую . к великомоу городоу . Серьбренъ1хъ Болгаръ...» ${ }^{11}$.

Отметим, в первую очередь, что неопределенность сведений о локализации «черных», «внутренних» и «серебряных» болгар дала основания некоторым исследователям связать их в одну систему. Так, Ф. Вестберг склонен был идентифицировать «внутренних» болгар $\mathrm{c}$ «черными» ${ }^{12}$. Во второй половине $\mathrm{XX}$ в. в исторической литературе получила распространение следующая концепция Н. Я. Мерперта, изложенная им в работе «Древнейшие болгарские племена Причерноморья» ${ }^{13}$. Придерживаясь традиционного мнения, он считал «черных» болгар прямыми наследниками Великой Болгарии и помещал их на огромной территории - от Днепра на восток до Кубани, включая Восточный Крым и Тамань. Как и Ф. Вестберг, Н. Я. Мерперт полагал, что «черные» болгары были тождественны «внутренним» болгарам восточных авторов, хотя первый этноним охватывает, по его мнению, население более обширной территории, чем второй. Внутренние болгары - это обитатели Днепро-Донского междуречья. К востоку от них до Кубани, по мнению Н. Я. Мерперта, жили собственно древние болгары - венендеры ${ }^{14}$. Однако у данной гипотезы есть один существенный недостаток: она не объясняет, как семантически были между собой связаны этнические названия «черные» и «внутренние» болгары. К тому же, данные о локализации этих групп болгар не совпадают.

Существует другая точка зрения, согласно которой термин «черные болгары» якобы был связан с другим этническим названием - «серебряные болгары». Так, Р. Бариев считает, что термин «серебряные болгары» должен означать «белые болгары» и принадлежал он барсилам, которые, по его мнению, в середине VIII в. переселились с Северного Кавказа на Среднюю Волгу. Те же болгары, которые остались в Предкавказье, считает исследователь, стали называться «черными» ${ }^{15}$. Однако в цветовой семантике многих народов, включая тюркоязычных булгар, термины «серебряный» и «белый» - это не одно и то же. Поэтому данная точка зрения остается лишь недоказанной гипотезой.

Гораздо более предпочтительными выглядят мнения о независимом происхождении отмеченных названий болгар. Вполне возможно, что локализация этих групп болгар может быть связана с семантическими значениями их названий. Так, относительно локализации «черных» болгар существует несколько подходов. Согласно первому, «черные» болгары должны были располагаться только в Восточном Приазовье, откуда они могли совершать свои рейды в Крым, согласно данным «Повести временных лет», через Керченский полуостров. Этого мнения придерживались М. И. Артамонов ${ }^{16}$, В. Т. Пашуто ${ }^{17}$, С. А. Ромашов ${ }^{18}$ и некоторые другие исследователи.

Однако данная локализация не соответствует сведениям Константина Багрянородного о «черных» болгарах. Поэтому более предпочтительной выглядит иная локализация этого подразделения болгар. Как уже отмечалось, Н. Я. Мерперт помещал их на огромной территории - от Днепра на восток до Кубани, включая Восточный Крым и Тамань ${ }^{19}$. Примерно к таким выводам пришел несколько лет назад А. А. Тортика. По его словам, картина 
выглядела следующим образом: «... методом исключения, для локализации Черной Болгарии остается только один район - восточная часть Северного Приазовья, примыкающая к Нижнему Дону и с севера ограниченная нижним течением Северского Донца. Ее западную границу можно предположить где-то в районе реки Молочной. Это участок степного пространства, вполне достаточный для размещения кочевой орды численностью в несколько десятков тысяч человек и способный, при условии договоренности с печенегами, совершать набеги на область Херсонеса. Период относительной самостоятельности этой орды, образованной, вероятно, из осколков различных родоплеменных групп протоболгар, входивших до этого в состав Хазарского каганата, был очень коротким - от нескольких десятилетий до половины столетия, что и отразили письменные источники середины $\mathrm{X}$ в.» ${ }^{20}$. Такая локализация учитывает как сведения «Повести временных лет», так и информацию Константина Багрянородного. Стало быть, имеется немало оснований для локализации «Черной Болгарии» именно в степях Северного Приазовья.

В связи с этим возникает естественный вопрос: не отразилась ли данная локализация территории «черных» болгар на возникновении этнотопонима? К сожалению, объяснение этого так и не удалось найти в болгароведческой литературе. Поэтому, чтобы разобраться в данном вопросе, необходимо иметь представление о том, какие семантические значения придавали тюрки, к числу которых относились и протоболгары, черному цвету.

Необходимо отметить, что уже раннесредневековые тюркоязычные кочевники использовали цвета для обозначения частей Света. Существует мнение, что данную традицию они заимствовали из Китая. С точки зрения ряда исследователей тюркоязычные кочевники для обозначения Севера использовали черный цвет, Востока - синий, Запада - белый, а Юга - красный. При этом иногда вместо белого цвета для обозначения Запада использовался желтый цвет ${ }^{21}$.

По наблюдениям О. Прицака, на протяжении всего Средневековья среди кочевников изменялось направление главной ориентации и тогда цветовая семантика должна была меняться в соответствии к тому, где находились главное направление, тыл, левый и правый фланги. По его версии, как уже было отмечено, изначально главные группы кочевников находились севернее и, соответственно этому, Север обозначался черным цветом. Однако со временем у тюркютов ориентация стала восточной и, соответственно этому, Восток стал обозначаться черным цветом, Юг - синим, Запад - красным, а Север - белым. При монгольской экспансии стала преобладать южная ориентация. Тогда черный цвет начал использоваться для обозначения Юга, синий - Запада, красный - Севера, а белый - Востока ${ }^{22}$.

Следует учитывать, что протоболгары принадлежали к числу раннесредневековых кочевников Евразии. Поэтому ориентация у них должна была быть северной. В соответствии с этим болгары могли обозначать Север черным цветом. Если следовать этой логике, то получается, что «черные» болгары, проживавшие в Северном Приазовье, должны находиться севернее остальных болгарских племен. Однако были еще болгары Среднего Поволжья, которые располагались дальше от всех остальных болгарских племен на СевероВосток. По предложенной схеме, их-то и следовало называть «черными». Но «черными» волжские булгары не были названы ни в одном письменном источнике. Таким образом, нет оснований считать, что на возникновение этнонима «черные болгары» должно было повлиять их географическое положение.

Отметим, что в номенклатуре тюркоязычных кочевников термин qara - «черный», имел множество иных семантических значений. По наблюдениям А. Н. Кононова, у тюркоязычных народов этот термин был известен в следующих значениях: 1) черный, хмурый, суровый, грустный, несчастный; 2) скот, толпа, народ, войско; 3) суша, земля; 4) холм, сопка, высокий холм. А. Н. Кононов отметил, что термин qara часто использовался в качестве первого элемента словосочетаний, которые обозначают: 1) этнонимы; 2) топонимы; 3) личную ономастику. По наблюдениям исследователя, в некоторых устойчивых словосочетаниях qara имеет ряд дополнительных значений: 1) великий, обильный; 2) главный, великий, могучий, крепкий; 3) сильный (о ветре, морозе); 4) чистый (без примесей); 5) суша, земля, материк; 6) темная (северная) сторона небосвода, север; 7) скот, толпа, войско, простолюдин, простой народ, чернь, раб, множество, масса ${ }^{23}$.

Однако термин «черные болгары» представляет собой этнонимическое название. Поэтому существенное значение может иметь информация именно этого плана. В связи 
с чем, обратим внимание на наблюдение Н. А. Баскакова, согласно которому у тюрков каждый этноним дифференцируется чаще всего двумя вариантами, которые базируются на противопоставлении (напр. кара кыпчак - ак кыпчак) ${ }^{24}$. Однако нам не известно ни одного упоминания о «белых болгарах». Как уже отмечалось, были попытки доказать, что термин «серебряные болгары» должен означать «белые болгары» 25 . Однако в тюркских языках термин кумус (серебро, серебряный) не был эквивалентом слов ак, capb, использовавшихся для обозначения белого цвета. Он применялся, прежде всего, для обозначения благородных металлов, казны и т.п. ${ }^{26}$. Таким образом, в названии «черные болгары» следует видеть этнический термин, существующий вне зависимости от этнонима, содержащего первую часть - «белый» (ак, сары). Это значительно сужает круг поисков.

Так, в названии «черные болгары» могла содержаться информация об антропологических особенностях носителей этнонима. В качестве аналогии вспомним мнение исследователей, что славянский по своему происхождению этноним половцы являлся эквивалентом тюркских названий куманы и кипчаки. Уже обращалось внимание на то, что в китайских источниках кипчаки были охрактеризованы как люди с голубыми глазами и светлым волосом. Именно это дало основание Н. А. Аристову и Г. Е. Грум-Гржимайло считать, что якобы в этногенезе половцев-кипчаков могли принять участие так называемые динлины, в которых Н. А. Аристов был склонен видеть индоевропейцев ${ }^{27}$, а Г. Е. Грум-Гржимайло аборигенов Дальнего Востока ${ }^{28}$.

В науке уже давно получило распространение мнение, что в основе этнических термином кипчак и куман следует искать тюркское слово куба/кыба - «бледный, бело-желтый, соломенно-желтый, т.е. половый». По мнению многих исследователей, такое название получила часть тюркских племен из-за первоначального цвета тела и лица ${ }^{29}$. Кроме того, Д. Е. Еремеев высказал предположение, что термин ку-ман состоял из двух составных частей и мог означать «песчаный (желтый) человек». Именно это дало ему основания считать, что славянское название половцы представляло собой кальку с тюркского термина сарык. До этого же типа этнонимов исследователь отнес и название оседлого жителя Средней Азии - capm (белый, бледнолицый), которое обозначало антропологические особенности аборигенов-нетюрков ${ }^{30}$.

В нашем случае, если исходить из того, что в названии «черные болгары» содержалось указание на антропологические особенности носителей этнонима, то придется признать, что эти болгары имели очень смуглый цвет кожи. Однако письменные источники об этом ничего не сообщают. Вряд ли болгары Приазовья по внешнему виду сильно отличались от других кочевников Восточной Европы.

В то же время, следует вспомнить предположение М. И. Артамонова, С. А. Плетнёвой, П. Голдена, Е. В. Радлова, О. Прицака и других исследователей, что у тюрков белый цвет мог означать благородное происхождение, а черный - низкий социальный статус, т.е. зависимое положение ${ }^{31}$. М. И. Артамонов даже высказался в пользу того, что болгары Приазовья назывались «черными», потому что пребывали в X в. в зависимом, подневольном положении у хазар ${ }^{32}$. Однако всё оказалось с точностью до наоборот. Вспомним высказывание Константина Багрянородного: «Черная Булгария может воевать с хазарами» ${ }^{33}$. Как отметил А. А. Тортика, в середине X в. эта орда на короткое время получила политическую самостоятельность ${ }^{34}$.

Стало быть, остается объяснить название «черные болгары» из оставшихся семантических значений термина qara. В связи с этим можно вспомнить предположение О. Прицака, что у тюрков термин qara мог иметь значение - «великий, главный». Это, по его мнению, было связано с тем, что в самом начале главные группы тюрков находились на Севере относительно остальных племен. Уместно вспомнить династию караханидов

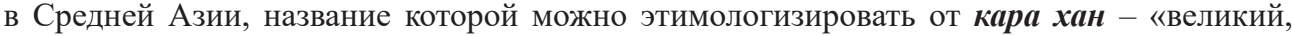
главный хан» ${ }^{35}$. Таким образом, получается, что термин «черные болгары» нес в себе значение «главные (великие) болгары», исходя из их независимого от хазар положения. Однако «великими» болгарами в письменных источниках иногда называли дунайских болгар из-за их независимого положения.

В итоге, метод исключения позволяет вспомнить еще одно семантическое значение термина qara - «чистый; без примесей; настоящий» ${ }^{36}$. Следовательно, этническое название «черные болгары» могло нести в себе семантическое значение - «настоящие болгары». 
В связи с этим следует напомнить, что Н. Я. Мерперт считал «черных» болгар прямыми наследниками Великой Болгарии ${ }^{37}$. Однако трудно отдать предпочтение одной из двух последних версий. Поэтому приходится признать, что болгар Северного Приазовья стали называть «черными» потому, что они вышли в середине X в. из-под контроля хазар и в глазах соседей предстали как прямые потомки пяти племен хана Кубрата, т.е. они стали «великими, настоящими» болгарами.

Не менее загадочным выглядит происхождение этнического термина «внутренние болгары», упоминаемого в «Худуд ал-“Алам». В свое время Й. Маркварт проявил интерес к данному вопросу и высказал предположение, что «внутренние» болгары мусульманских авторов имеют отношение к дунайским болгарам ${ }^{38}$. Однако наиболее обоснованный вид данная гипотеза получила в комментариях В. Ф. Минорского к «Худуд ал-'Алам». Там исследователь высказал предположение, что деление болгар на «внешних» и «внутренних» в географическую литературу предположительно мог ввести ал-Балхи (850-934 гг.), который в своей «Книге видов Земли» описал страну волжских булгар и упомянул о находившемся там «Внешнем Булгаре» ${ }^{39}$.

По наблюдениям В. Ф. Минорского, впервые термин «внутренние болгары» мог использовать ал-Истахри (около 850-934 гг.) в своем сочинении «Китаб ал-масалик ва-лмамалик» («Книга путей и стран»). Он несколько раз упоминает о них. Так, в первый раз ал-Истахри сообщает, что русы торгуют с хазарами, Византией и Великой Болгарией (Bulghār al-a'zam). При этом арабский географ уточняет, что они (русы) граничат с севера с Византией и их количество значительно. Их могущество известно из-за того, что они обложили хараджем (данью) Византию и «внутренних» болгар, которые проживают возле их страны. Далее он добавляет, что «внутренние» болгары - христиане ${ }^{40}$. В другом фрагменте содержится почти такой пассаж, но вместо русов упомянута «Великая Болгария», которая также граничит с Византией с севера и собирает с последней дань. И тут же сказано, что среди «внутренних» болгар есть христиане и мусульмане ${ }^{41}$. Кроме того, ал-Истахри упоминает «внутренних» болгар в связи с сюжетом о Гоге и Магоге. По его словам, меридиан проходит с севера на юг через владения сакалибов, «внутренних» болгар и идет вдоль Византии и Сирии ${ }^{42}$.

Такая запутанная и противоречивая информация как ал-Истахри, так и анонимного автора «Худуд ал-'Алам» заставила В. Ф. Минорского сделать предположение, что термин «внутренние болгары» явно противопоставлялся термину «внешние болгары» (Bulghār al-khārija), который у ал-Истахри был упомянут как «небольшой город». В результате, В. Ф. Минорский посчитал, что дунайские болгары были известны у различных мусульманских авторов под отличающимися названиями: у Ибн Хаукаля как «бурджан»; у Ибн Русте - «болгар»; у ал-Истахри - «внутренние болгары»; а у Гардизи - «В.н.н.д.р» ${ }^{43}$. Однако не все исследователи придерживались дунайской локализации «внутренних» болгар.

Так, В. В. Бартольд основывался, в первую очередь, на данных «Худуд ал-“Алам», а это позволило ему локализовать «внутренних» болгар гораздо восточнее. По его мнению, этнополитическая ситуация на юге Восточной Европы в середине X в. выглядела следующим образом: «С мусульманскими владениями на Кавказе, по нашему автору (38a) с Арменией, в действительности с Дербентом и южной частью Дагестана граничила область сериров (авар), примыкавшая на западе к Византии. К северу и западу от сериров жили аланы, область которых примыкала уже только к Византии, а не к мусульманским владениям; на севере область алан доходила до Черного (или Азовского) моря и до владений печенегов хазарских. Печенеги хазарские, северные соседи алан, жили уже не к югу, а к востоку от Черного моря; восточную границу их области составляли «хазарские горы», т.е. горы, составлявшие, по мнению автора, западную границу хазарской области; по его представлению (8a), горы шли от Каспийского моря на запад между владениями сериров и хазар до начала пределов алан, потом направлялись к северу до конца владений хазар, потом проходили между областями печенегов хазарских, внутренних болгар и русов $<\ldots>$ до пределов славян, потом проходили на север посреди области славян мимо славянского города Хурдаба, потом доходили до конца области славян. К западу от гор (вероятно, тех же), к северу от Черного моря и к северо-западу от хазарских печенегов жили мирваты (хазарские печенеги были для них частью восточными, частью южными соседями); Черное море примыкало к их области с запада. К северо-западу от мирватов и также к северу от 
Черного моря жили внутренние болгары, область которых доходила на севере до «русских гор». Последней к западу областью на северном берегу Черного моря была область славян, граничившая на юге также с Византией. Восточными соседями славян, кроме внутренних болгар, были также русы; на севере и на западе к области славян примыкали «безлюдные пустыни севера». С теми же пустынями граничила на севере область русов, доходившая на юге до Дуная, на котором находился и главный город славян Хурдаб» ${ }^{44}$. Отметим сразу, что В. В. Бартольд назвал «славянами» сакалибов, что не совсем одно и то же. Таким образом, исследователь склонен был локализовать «внутренних» болгар на север от Черного моря, и они, по его мнению, находились между Русью и «хазарским печенегами» и загадочными «мирватами».

В данной ситуации необходимо выяснить, являлся ли термин «внутренние болгары» самоназванием части болгар или же это было выдуманное мусульманским географами название народа? В пользу первой версии говорит существование аналогичных названий среди других тюркоязычных народов. Весьма показательны в этом отношении, например, огузы.

При анализе социальной структуры огузских племен особый интерес представляют сведения огузского эпоса «Деде Коркут» (XV в.), по данным которого каждое огузское племя делилось на «внешних» и «внутренних». При этом во время войны «внутренние» огузы занимали центр и левое крыло, а «внешние» - правое ${ }^{45}$. Если учитывать, что огузы придерживались традиционной северной ориентации ${ }^{46}$, то «внутренние» огузы представляли западную часть, а «внешние» - восточную. А это может означать, что при формировании огузского союза племен этот принцип переносился на высший уровень объединения, т.е. огузам было присуще, как и другим средневековым кочевникам, разделение на западную и восточную группировки ${ }^{47}$. При этом западные племена огузов стали называться «внутренними», а восточные - «внешними». Ничто не мешает нам считать, что подобная картина наблюдалась и среди раннесредневековых болгар.

По мнению О. Прицака, на протяжении всего Средневековья направление главной ориентации среди кочевников менялось. Изначально преобладала северная ориентация, потом - восточная, а во времена Чингиз-хана - южная. Таким образом, левое и правое крыло в военно-территориальной системе кочевников находились изначально соответственно на западе и востоке, а через несколько столетий все стало с точностью до наоборот - левое крыло стало восточным, а правое переместилось на запад ${ }^{48}$. Достаточно посмотреть на карту Монголии, чтобы убедиться в этом - Внутренняя Монголия находится восточнее Внешней (Халха) Монголии. Учитывая то, что раннесредневековые болгары имели северную ориентацию, имеет резон локализовать племена левого крыла их объединения на западе, а правого крыла - на востоке. Поэтому не исключено, что западные племена болгар могли называться «внутренними», а восточные - «внешними».

В соответствии этому можно прокомментировать сообщение ал-Балхи о волжских булгарах в несколько иной плоскости. Напомним, что он упомянул о «Внешнем Булгаре» ${ }^{49}$. По-видимому, здесь речь об одном из городских поселений, которые являлись административно-экономическими центрами племен, изначально входивших в объединение волжских булгар.

Об этническом составе булгар Средней Волги письменные источники начали писать лишь в X в. Достаточно детальное описание этих булгар нам оставили мусульманские информаторы. По их свидетельствам, волжские булгары были неоднородны. Так, Ибн Русте (X в.) и Гардизи (XI в.) сообщают, что волжские булгары делятся на три группы: б.рсула, аскел и собственно булгар ${ }^{50}$. Однако информация Ибн Фадлана позволяет считать, что ранее в состав племенного союза булгар Средней Волги входило и четвертое племя суваз или сувар ${ }^{51}$. Стало быть, в сообщении ал-Балхи содержится информация о реалиях второй половины IX в., когда племен в союзе волжских булгар было еще четыре. В соответствии этому, под названием «Внешний Булгар» можно видеть центр одного из племен этого объединения.

С другой стороны, становится понятно, почему ал-Истахри назвал дунайских богар «внутренними» ${ }^{52}$. Ведь они, по мнению его информаторов, являлись наиболее западной группой всех болгар. Вполне очевидно, что обозначение этих болгар термином «внутренние» могло попасть в сочинение ал-Истахри через посредство балканских информаторов, которые не имели четкой информации о восточных группах болгар. Этим-то и можно 
объяснить отсутствие в сочинении ал-Истахри сведений о «внешних» болгарах. Аналогичную картину наблюдаем и в «Худуд ал-'Алам». Но там отсутствие сведений о «внешних» болгарах можно объяснить иными факторами.

В первую очередь, в трактате имеется шесть упоминаний о «внутренних» болгарах. Из них, в пяти случаях, они обозначены термином Bulghār-i dākhil ${ }^{53}$ и лишь в одном случае их обозначением стало выражение Bulghār-i andarūni ${ }^{54}$. По данным Ф. Штайнгасса, термины andarūni и dākhil действительно можно перевести с персидского как «внутренние», хотя первый имеет больше семантических значений ${ }^{55}$. Необходимо отметить, что в том фрагменте трактата, где для обозначения болгар использован термин Bulghār-i andarūni, oтмечено, что от земли этих болгар «расположена некоторая часть моря Гурз (Черного - О. Б.) и некоторая часть Рума (Византии - О. Б.) $\rangle^{56}$. Это как-то не согласуется с остальной информацией «Худуд ал-“Алам» о внутренних болгарах, хотя очень напоминает сведения о них у ал-Истахри ${ }^{57}$. На основании этого можно сделать предположение, что источников о «внутренних» болгарах у автора «Худуд ал-'Алам» было, как минимум, два. А это вполне соответствует выводам исследователей, что данный трактат представляет собой сложное компилятивное сочинение.

С другой стороны, важно выяснить, почему в «Худуд ал-“Алам» содержатся сведения лишь о «внутренних» болгарах и нет сведений о «внешних болгарах»? Если следовать предложенной схеме, то получается, что «внешними» должны быть булгары Среднего Поволжья.

Однако, говоря о населении Среднего Поволжья для обозначения жителей левого берега, где раньше были известные булгары, автор «Худуд ал-“Алам» использовал, но уже нетрадиционно, известный ранее этноним б-ртас. Относительно локализации области б-ртас он сообщает: «Слово об области Буртас. С востока и юга ее - гузы, с запада - река Атиль, с севера - область печенегов». Уже сама такая локализация буртасов противоречит данным других мусульманских авторов, которые традиционно локализуют их не к востоку от Волги (Итиля), а на западном берегу реки. Кроме того, вызывает определенное удивление и другая информация об области б-рmac: «Люди ее мусульмане. У них язык трудный для понимания. Государя называют Мес, владеют телегами и палатками. Их три группы: б-хдула, аш-к-л, б-лкар. Все они друг с другом в войне находятся, когда же появляется какой-либо враг - друг с другом друзья» ${ }^{58}$. Исследователи уже давно обратили внимание на то, что данные «Худуд ал-“Алам» о народе б-рmac во многих чертах повторяют информацию Ибн Русте о волжских булгарах. Что же касается информации о собственно «буртасах» большинства средневековых авторов, то в «Худуд ал-“Алам» она соотносится с данными о народах области барадзас.

Относительно территории «барадзасов» (собственно буртасов) «Худуд ал-“Алам» сообщает: «Слово об области Барадзас. Эта область, с востока которой река Атель, с юга ее - хазары, с запада - в-н-н-д-р, с севера - печенеги-тюрки». Таким образом, есть основания локализовать часть «барадзасов» не только на Средней Волге, но и в степях Волго-Донья, вблизи от хазар. Сведения об образе жизни «барадзасов» также полностью соотносятся с информацией предыдущих мусульманских авторов о буртасах ${ }^{59}$.

Комментируя этот пассаж, А. П. Новосельцев пришел к выводу, что анонимный автор «Худуд ал-“Алам», «найдя у своих предшественников две формы названия одного народа буртасов - буртас и бердас, принял их за разные этнонимы ${ }^{60}$. Однако этноним б-радзас или барадзас до конца X в. не фигурировал в сочинениях предыдущих арабо-мусульманських авторов, хотя у Ибн Русте встречается похожая форма этнонима - $\boldsymbol{\sigma}-\boldsymbol{p}$-дас $\boldsymbol{c}^{61}$. По мнению Д. Е. Мишина, «такая графическая разница оказалась, по-видимому, для автора "Худуд ал-“Алам" непреодолимым препятствием, и в его книге “буртас" и "б.рдзас" фигурируют как различные народы» ${ }^{62}$.

Как видим, сведения о волжских булгарах и «внутренних» болгарах были взяты автором «Худуд ал-'Алам» из различных источников. Анонимный автор трактата предпочел вообще заменить традиционное обозначение для волжских булгар на «буртас». Неизвестно, было ли в источнике, откуда автор «Худуд ал-“Алам» взял информацию о «внутренних» болгарах, обозначение для волжских болгар - «внешние болгары».

В связи с этим, возникает также ещё один вопрос: почему анонимный автор «Худуд ал-“Алам» не использовал название «внутренние болгары» для обозначения самой запад- 
ной группы болгар, которые проживали на Дунае? В связи с этим отметим, что исследователи уже неоднократно высказывали мнение, что в этом трактате они были названы термином $\boldsymbol{6}-\boldsymbol{H}-\boldsymbol{H}-\boldsymbol{\partial}-\boldsymbol{p}^{63}$. В «Худуд ал-“Алам» об области $\boldsymbol{B}-\boldsymbol{H}-\boldsymbol{H}-\boldsymbol{\partial}-\boldsymbol{p}$ сказано: «К востоку от нее - барадзасы (буртасы - O. Б.); к югу от нее - хазары; к западу от нее - горы; к северу от нее - мадьяры. Они (жители этой страны - О. Б.) трусливы, слабы, бедны и владеют некоторыми вещами» ${ }^{64}$. Подобный этноним - $\boldsymbol{\sigma}-\boldsymbol{\mu}-\boldsymbol{H}-\boldsymbol{m}-\boldsymbol{p}-$ был также отмечен в Пространной редакции письма хазарского царя Иосифа ${ }^{65}$. Не исключено, что данное этническое название может быть связано с одним из обозначений для гунно-болгар - хунногундур.

В конечном итоге можем констатировать, что анонимный автор «Худуд ал-“Алам» использовал сочинения своих предшественников - мусульманских географов IX-X вв., для создания собственной картины мира. Естественно, это столкнулось с рядом трудностей, связанных с отличающейся терминологией для обозначения народов у различных географов. Это заставило анонимного автора трактата отказаться от многих фрагментов предыдущих сочинений, а оставшийся материал подвергся значительной обработке. Это хорошо видно на примере болгар, сведения о которых под названием «внутренние болгары» вошли в трактат, а информация о «внешних» уже не была использована.

Исходя из сказанного, складывается впечатление, что информация о «внутренних» болгарах попала к информаторам «Худуд ал-“Алам» из Хазарии. Стало быть, здесь речь идет о болгарах, проживавших на территории Хазарского каганата. Следует напомнить, что дунайских болгар автор трактата назвал $\boldsymbol{6}-\boldsymbol{H}-\boldsymbol{H}-\boldsymbol{\partial}-\boldsymbol{p}$, а волжских булгар - б-pmac. Метод исключения позволяет не относить дунайских и волжских болгар к «внутренним». Таким образом, вполне очевидно, что анонимный автор «Худуд ал-“Алам» назвал «внутренними», т.е. западными, тех болгар, которые проживали в степях Подонья и Приазовья. Это предположение полностью соответствует схеме В. В. Бартольда, согласно которой владения «внутренних» болгар находились на север от Черного моря, граничат с Русью и «хазарскими печенегами», проживавшими в Восточном Приазовье $\mathrm{e}^{66}$.

Не менее неоднозначна ситуация и с использованием термина «серебряные болгары». Так, исходя из сообщения Ипатьевской летописи, где речь идет о походе Руси на Волжскую Булгарию в 1183 г., уже мало кто сомневается в том, что «серебряные» болгары являлись одним из подразделений волжских булгар. В свое время востоковед В. В. Григорьев выдвинул гипотезу, базирующаяся на лексическом материале восточных языков. Рассматривая проблему этногенеза волжских булгар, он отметил: «О булгарах серебряных или нукратских: эти, как видно, жили по Каме, вероятно поблизости каких-нибудь серебряных рудников, от которых получили свое имя; “нукрат" слово арабское, значит “серебро"»67. Еще несколько десятилетий назад Б. Д. Греков и Н. Ф. Калинин пытались доказать, что этноним берсула имел отношение к «нукратским» татарам и являлся переводом термина «серебряные болгары». Это предположение базировалось на том, что слово нокра на персидском языке означает «серебро», а термины бер и сер, по их мнению, могли соответственно означать средневолжское племя берсула и сер - «серебро» ${ }^{68}$. Данная этимология получила распространение и в современной литературе. Так, Р. Г. Фахрутдинов в своем исследовании о волжских булгарах пишет, «что “серебряные булгары” являются русским переводом предполагаемого племени "нухратские булгары” (“нухрат” в переводе с арабского значит “серебро")» ${ }^{69}$.

В связи с этим обратим внимание на мнение И. Л. Измайлова, которое сводится к следующему: «некоторые историки пытаются сконструировать некую общность под названием “нукратских булгар", якобы восходящую к берсула и идентичную “серебряным болгарам" (“нократ” - по-персидски “серебро"). Данная гипотеза, возникшая под воздействием "яфетической” теории Н. Я. Марра (“Бер" = берсула, “сер" = “серебро"), уязвима для критики. Такое название никак не может быть связано ни с серебром, ни с булгарами ни с точки зрения филологии (происхождение татарского названия гидронима Вятка (Hyкpam cybl) восходит к названию Новгорода (Нукрат), которому принадлежали Вятские земли), ни с точки зрения истории, поскольку не фиксируется ни в одном средневековом источнике. Попытки же конструирования неких “нукратских/серебряных булгар”, якобы живших по Вятке и Каме, несостоятельны, поскольку в русских источниках "серебряные булгары” отмечаются только под этим названием и в районе Биляра (“Великого города” русских летописей)» ${ }^{70}$. 
Как видим, проблема происхождения названия «серебряные болгары» так и не нашла сколь-нибудь убедительного объяснения у историков. Однако отметим при этом еще один существенный момент: на сегодня практически все исследователи полностью уверены, что серебряные болгары проживали лишь на Средней Волге, ссылаясь при этом на сообщение Ипатьевской летописи от 1183 г. Отсюда и видим попытку решить проблему, исходя лишь из реалий Среднего Поволжья. Однако обстоятельства упоминания «серебряных болгар» в сочинении Иакова Мниха заставляют усомниться в устоявшемся мнении.

Сравним события, описанные в произведении Иакова Мниха, с информацией «Повести временных лет». Там последовательность походов несколько иная. Сначала в летописи говорится о военных рейдах князя Владимира против вятичей в 981 и 982 гг.: «[6489 (981)] Иде [Володимеръ] к Ляхомъ и за градъ1 их . Перемъшль Червенъ . и инъ1 градъ1 . єже суть и до сего дне подъ Русью . В сем же лете и Вятичи победи . и възложи на нь дань ... [6490 (982)] Заратишася Вятичи и иде на ня Володимирь . и победи є второе» ${ }^{71}$. В следующем 983 г. Владимир пошел на ятвягов, о чем в «Повести временных лет» сказано: «[6491 (983)] Иде Володимеръ на Явтяги . и побед Явтяги . и взя землю их» ${ }^{72}$. Только в 984 г. Владимир пошел на радимичей. Об этом Лаврентьевская летопись сообщает: «[6492 (984)] Идє Володимеръ на Радимичи . бе оу него воєвода Вольчии Хвость . и посла и Володимеръ передъ собою Вольчье Хвоста . сьрете $є$ на реце Пищане . и победи Радимиче Вольчии Хвость . темь и Русь корятся Радимичемъ глюще . Пищаньци вольчье хвоста бегають . быша же Радимичи о рода Ляховъ . прешедъше ту ся вселиша . и платять дань Руси . повозъ везуть и до сего дне» ${ }^{73}$.

А далее в летописи сообщается о походе Владимира против болгар в 985 г.: «Иде Володимер на болгары с Добрынею . уем своим . в лодьях . а торки берегом приведе на коних . и победи болгары. рече Добрына Володимеру . съглядахъ колодникъ . оже суть вси в сапозех . симъ дани намъ не даети . поидемъ искатъ лапотниковъ . и створи миръ Володимеръ съ Болгары . и роте заходиша межю собе . и реша Болгаре . толи не будеть межю нами мира . єлико камень начнеть плавати а хмель почнет тонути . и приде Володимеръ Києву...» ${ }^{74}$. Сведений о походе на хазар у автора «Повести...» почему-то нет. После этого под 986 г. речь идет о религиозном диспуте, в котором участвовали болгары-мусульмане и хазары-иудеи. Для сравнения напомним, что Иаков Мних упоминает о походах в такой последовательности: радимичи, вятичи, ятвяги, серебряные болгары, хазары ${ }^{75}$.

Относительно комментирования упомянутых в «Повести временных лет» событий 985 г. мнения исследователей разделились. Так, С. А. Плетнева, придерживаясь мнения о появлении торков-огузов в южнорусских степях лишь в начале XI в., отмечала, что киевский князь Владимир воевал против волжских булгар, а торки-огузы во время этого похода двигались на север вдоль левого берега Волги ${ }^{76}$. Академик П. П. Толочко считает, что Владимир совершил поход на Волжскую Болгарию. Относительно участия в этом походе торков он высказал следующее мнение: «Предположение об участии в походе 985 г. саркельских гузов кажется более естественным, нежели вывод об их нижневолжских соплеменниках, отстоявших от границ Руси на многие сотни километров» ${ }^{77}$. Особый интерес представляет мнение А. П. Новосельцева, который считал, что киевский князь совершил нападение на приазовских болгар, а не на волжских ${ }^{78}$. В пользу последней версии напомним, что в конце X в. болгары продолжали проживать в степях Приазовья.

Таким образом, сравнение фрагмента из сочинения Иакова Мниха с сообщением «Повести временных лет» о походе Владимира в 985 г. позволило некоторым историкам считать, что в обоих древнерусских текстах речь идет об одних событиях, в которых принимали участие якобы «серебряные болгары» из Среднего Поволжья. Однако исследователи не могут объяснить, каким образом к этим событиям были причастны хазары, которые в конце X в. могли проживать более чем на тысячу километров от Волжской Булгарии - в устье Волги или на Тамани. Учитывая это, возникает сомнение, что упомянутые в сочинении Иакова Мниха «серебряные болгары» в конце X в. жили только на Средней Волге.

В связи с этим стоит обратить внимание на одну важную деталь: термин «серебряные болгары» встречается только в древнерусских текстах. А это может только означать, что он не является калькой с тюркского или других языков и объяснение его следует искать в древнерусском языке. По наблюдениям И. И. Срезневского, в древнерусском языке слово «серебреныи» имеет два семантических значения: «сделанный из серебра» и 
«денежный» ${ }^{79}$. Именно последнее значение хорошо соотносится с двумя упоминаниями о «серебряных болгарах». Так, в 1183 г. они упоминаются как жители в «великомоу городоу» ${ }^{80}$, под которым подразумевают Биляр ${ }^{81}$. Ничто не мешает нам считать, что не случайно жители этого большого городского центра Волжской Болгарии были названы летописцем именно «денежными». Ведь ни для кого не секрет, что основной целью большинства военных походов была материальная добыча.

Отождествление «серебряных болгар» Иакова Мниха с болгарами, против которых воевал Владимир в 985 г., является вполне логичным, если вспомнить сообщения летописи об изобилии этих болгар: «оже суть вси в сапозех» ${ }^{82}$. И. А. Гагин обратил внимание на этот пассаж и прокомментировал его следующим образом: «Сапоги пленных - отдельный вопрос, раскрывающий картину экономического благосостояния населения страны, на которую был совершен поход». Этой страной исследователь считал Волжскую Булгарию ${ }^{83}$. Однако богатыми могли быть не только булгары Средней Волги, но также дунайские и приазовские болгары. Кроме того, последние были еще и соседями хазар Тамани. Возникает естественный вопрос: не могли ли болгары Восточного Приазовья обогащаться за счет контроля над торговыми путями или разработками добычи драгоценных металлов? Последнее предположение может иметь под собой даже материальную основу.

Так, французский историк начала XIX в. Де ля Примод, ссылаясь на данные генуэзских документов, отмечает, что в XIV в. генуэзские купцы имели на Тамани свою колонию, через которую они осуществляли торговлю «с народами Кубани и Кавказа». Кроме того, историк пишет: «Генуэзцы разрабатывали также серебряные рудники в Кавказских горах; следы их работ видны и поныне» ${ }^{84}$.

Имеются свидетельства того, что и в XVIII в. в Прикубанье продолжали добывать серебро. Например, Н. М. Карамзин охарактеризовал современную ему ситуацию на Северо-Западном Кавказе так: «Доныне находится много Жидов в земле Черкесской, и Буртанами называется теперь особенный, неизвестного происхождения народ между Кубанью и Актаром, богаты медью и серебром» ${ }^{85}$. Эту же информацию подтверждает Тунманн, побывавший в XVIII в. в Приазовье. По его словам: «Буртани, или Бриттани, племя, отличающееся от черкесов и ногайцев. Они живут между Кубанью и Актаром, свободны и независимы, остаются на одном месте и имеют в изобилии серебро и медь» ${ }^{86}$. Добавим, что Актар - это город на восточном побережье Азовского моря.

Следовательно, не исключено, что в конце X в. болгары Восточного Приазовья могли раньше генуэзцев заниматься разработкой серебра на территории, прилегающей к Тамани. Таким образом, упомянутый Иаковом Мнихом термин «сребныя Болгары» вообще может означать - «богатые на серебро болгары». Получается, что эта группа болгар проживала не на Средней Волге, а в Восточном Приазовье рядом с Таманским полуостровом, где жили хазары.

Таким образом, упомянутые в сочинении Иакова Мниха «Память и похвала князю русскому Владимиру» и в Ипатьевской летописи под 1183 г. «серебряные болгары» могли проживать как на Средней Волге, так и в Восточном Приазовье. Предложенная этимология термина «серебряные болгары» как «денежные болгары» вполне может соответствовать благосостоянию упомянутых групп болгар, что вполне согласуется с данными письменных источников.

В итоге, приходится констатировать, что обозначения для болгарских племен Восточной Европы - «черные болгары», «внутренние болгары» и «серебряные болгары» не были между собою связаны семантически. Тем не менее, довольно часто они могли обозначать одни и те же группы болгар. Так, термин «внутренние болгары» мог означать не только болгар Подонья, но и покрывал «черных» болгар из Северного Приазовья и «серебряных» болгар из Восточного Приазовья. Такая ситуация стала следствием того, что упомянутые этнические термины дошли до нас из различных письменных источников.

${ }^{1}$ Константин Багрянородный. Об управлении империей / Под ред. Г. Г. Литаврина и А. П. Новосельцева. М., 1991. С. 53.

${ }^{2}$ Там же. С. 175.

3 Лаврентьевская летопись // Полное собрание русских летописей (далее - ПСРЛ). Т. І. Л., 19261928. C. 37. 
4 Худуд ал-“Алем (рукопись Туманского) с введением и указателем В. Бартольда. Л., 1930. Табл. 3а; Minorsky V. Hudud al-'Alam. The regions of the world. London-Oxford, 1937. P. 54.

${ }^{5}$ Худуд ал-“Алем. Табл. 8a; Minorsky $V$. Hudud al-‘Alam. P. 67.

${ }^{6}$ Худуд ал-'Алем. Табл. 13a; Minorsky $V$. Hudud al-‘Alam. P. 83.

${ }^{7}$ Худуд ал-‘Алем. Табл. 37b; Minorsky V. Hudud al-‘Alam. P. 158.

${ }^{8}$ Худуд ал-'Алем. Табл. 38a, C. 30-31; Minorsky V. Hudud al-'Alam. P. 160.

9 Там же.

10 Зимин А. А. Память и похвала Иакова Мниха и Житие князя Владимира по древнейшему списку // Краткие сообщения Института славяноведения АН СССР. Вып. 37. М., 1963. С. 71.

${ }^{11}$ Ипатьевская летопись // ПСРЛ. Т. ІІ. СПб., 1908. С. 429.

12 Вестберг Ф. Записка готского топарха // Византийский временник. 1910. Т. ХV. С. 243-244; Его же. К анализу восточных источников о Восточной Европе // Журнал министерства народного просвещения (далее - ЖМНП). 1908. Февр. С. 386-389.; Minorsky V. Hudud al-'Alam. P. 439.

${ }_{13}$ Мерперт Н. Я. Древнейшие болгарские племена Причерноморья // Очерки истории СССР / Под ред. Б. А. Рыбакова. М., 1958. С. 586-615.

${ }_{14}$ Там же. С. 604-608, 615.

${ }^{15}$ Бариев Р. Х. Волжские булгары: история и культура. М. 2005. С. 61.

${ }^{16}$ Артамонов М. И. История хазар. Л., 1962. С. 378.

${ }_{17}$ Пашуто В. Т. Внешняя политика Древней Руси. М., 1968. С. 65.

${ }^{18}$ Ромашов C. А. Где находилась Черная Болгария? // Восточная Европа в древности и средневековье. Спорные проблемы. М., 1993. С. 63-68.

${ }^{19}$ Мерперт Н. Я. Древнейшие болгарские племена Причерноморья. С. 604-608, 615.

${ }_{20}$ Тортика A. A. «Чёрная Булгария» трактата Константина Багрянородного «Об управлении империей» и «чёрные болгары» «Повести временных лет»: проблемы локализации // Дриновський збірник/Дриновски сборник. Т. 5. Харків-Софія, 2012. С. 30.

${ }^{21}$ Pritsak $O$. Orientierung und Farbsymbolik. $\mathrm{Zu}$ den Farben Bezeichnungen in den altaishen Volkernamen // Pritsak O. Studies in Medieval Eurasian History. London, 1981. S. 376-377; Кононов А. Н. Семантика цветообозначений в тюркских языках // Тюркологический сборник. 1975. М., 1978. C. $159-179$.

${ }^{22}$ Pritsak O. Orientierung und Farbsymbolik. S. 376-377; Pritsak O. Qara. Studie zur Türkischen Rechtssymbolik // Pritsak O. Studies in Medieval Eurasian History. London, 1981. S. 248-250.

${ }^{23}$ Кононов А. Н. Семантика цветообозначений в тюркских языках // Тюркологический сборник. 1975. М., 1978. С. 161-169.

${ }^{24}$ Баскаков Н. А. Модели тюркских этнонимов и их типологическая классификация // Ономастика Востока. М., 1980. С. 204-206.

${ }^{25}$ Бариев Р. Х. Волжские булгары: история и культура. С. 61.

${ }^{26}$ Радлов В. В. Опыт словаря тюркских наречий. Т. ІІ. Ч. 2. СПб., 1899. Стб. 1527.

${ }^{27}$ Аристов Н. А. Заметки об этническом составе тюркских племен и народностей и сведения об их численности // Живая старина. Вып. III-IV. 1896. С. 323, 352.

${ }^{28}$ Грум-Гржсимайло Г. Е. Западная Монголия и Урянхайский край. Т. II. М.-Л., 1926. С. 9-126, 131, 142, 160-165, 184, 193-194, 197, 210-211, 350-354, 357.

${ }^{29}$ Петров К. И. Очерк происхождения киргизского народа. Фрунзе, 1963. С. 67; Ураксин 3. Г. Цветовые обозначения в башкирских этнонимах // Башкирская этнонимия. Уфа, 1987. С. $129-131$.

${ }^{30}$ Еремеев Д. Е. К семантике тюркской этнонимии // Этнонимы. М., 1970. С. 135-138.

${ }_{31}$ Артамонов М. И. История хазар. Л., 1962. С. 400; Плетнева С. А. Хазары. М., 1980. С. 48-49; Golden P. Khazar Studies. Vol. 1. Budapest, 1980. Р. 143; Радлов В. В. Опыт словаря тюркских наречий. Т. І. Ч. 1. СПб., 1893. Стб. 88-89; Радлов В. В. Опыт словаря тюркских наречий. Т. II. Ч. 2. СПб., 1899. C. 138-141; Pritsak O. Qara. Studie zur Türkischen Rechtsymbolik // Pritsak O. Studies in Medieval Eurasian History. London, 1981. P. 383.

${ }_{32}$ Артамонов М. И. История хазар. Л., 1962. С. 170-171.

${ }^{33}$ Константин Багрянородный. Об управлении империей / Под ред. Г. Г. Литаврина и А. П. Новосельцева. М., 1991. С. 53.

${ }^{34}$ Тортика A. A. «Черная Булгария» трактата Константина Багрянородного «Об управлении империей» и «черные болгары» «Повести временных лет»: проблемы локализации. С. 30.

${ }^{35}$ Pritsak O. Qara. Studie zur Türkischen Rechtsymbolik. P. 377.

${ }^{36}$ Кононов А. Н. Семантика цветообозначений в тюркских языках // Тюркологический сборник. 1975. M., 1978. C. 161-169.

${ }^{37}$ Там же. С. 604-608, 615.

${ }^{38}$ Marquart I. Osteuropäische und Ostasiatische Streifzüge. Leipzig, 1903. S. 503-506, 517-519.

${ }^{39}$ Minorsky $V$. Hudud al-‘Alam. P. 438-439.

${ }^{40}$ Minorsky $V$. Hudud al-‘Alam. P. 438-439.

${ }^{41}$ Minorsky $V$. Hudud al-'Alam. P. 439.

${ }^{42}$ Minorsky $V$. Hudud al-'Alam. P. 439. 
${ }^{43}$ Minorsky $V$. Hudud al-'Alam. P. 440.

${ }^{44}$ Худуд ал-’Алем (рукопись Туманского) с введением и указателем В. Бартольда. Л., 1930. С. 29.

${ }^{45}$ Курылев В. П. Общественный строй огузов по данням эпоса «Деде Коркут») / VII международный конгресс антропологических и этнографических наук (Москва, август, 1964 г.). М., 1964. С. 2-5.

${ }^{46}$ Кононов А. Н. Семантика цветообозначений в тюркских языках // Тюркологический сборник. 1975. M., 1978. C. 164.

${ }^{47}$ Курылев В. П. Общественный строй огузов по данням эпоса «Деде Коркут». С. 2-5.

48 Pritsak $O$. Orientierung und Farbsymbolik. $\mathrm{Zu}$ den Farben Bezeichungen in den altaishen Volkernamen. S. 381-382.

${ }^{49}$ Minorsky V. Hudud al-'Alam. P. 438-439.

50 Заходер Б. Н. Каспийский свод сведений о Восточной Европе. Т. ІІ. Булгары, мадьяры, народы севера, печенеги, русы. М., 1967. С. 28, 48.

${ }_{51}$ Ковалевский А. П. Книга Ахмеда ибн-Фадлана о его путешествии на Волгу в 921-922 гг. Харьков, 1956. С. $138-139$.

${ }^{52}$ Minorsky V. Hudud al-'Alam. P. 438-439.

53 Худуд ал-'Алем (рукопись Туманского) с введением и указателем В. Бартольда. Л., 1930. Табл. 3а, 13a, 38а. C. 30-31; Minorsky V. Hudud al-'Alam. P. 54, 67, 83, 160.

${ }^{54}$ Худуд ал-'Алем. Табл. 37b; Hudud al-'Alam. Р. 158.

${ }^{55}$ Steingass F. A Comprehensive Persian-English Dictionary. Beirut, 1998. P. 109, 494.

${ }^{56}$ Худуд ал-'Алем - Табл. 37b; Hudud al-'Alam. Р. 158.

${ }^{57}$ Hudud al-'Alam. P. 438-439.

${ }^{58}$ Туманский А. Буртас и Бердас // Известия Высших Тифлисских женских курсов. Кн. 1. Вып. 1. Тифлис, 1914. С. 95-96; Худуд ал-'Алем. Табл. 38б.

${ }^{59}$ Туманский А. Буртас и Бердас. С. 95-96; Худуд ал-“Алем. Табл. 386.

${ }^{60}$ Новосельцев А. П. Хазарское государство и его роль в истории Восточной Европы и Кавказа. M., 1990. C. 18.

${ }^{61}$ Хвольсон Д. А. Известия о хазарах, болгарах, мадьярах, славянах и русах Абу-Али Ахмеда Бен Омар ибн-Даста. СПб., 1869. С. 19-21.

${ }^{62}$ Мишин Д. Е. Географический свод «Худуд ал-“Алам» и его сведения о Восточной Европе // Славяноведение. 2000. № 2. С. 57.

${ }^{63}$ Hudud al-'Alam. P. 465-471.

${ }^{64}$ Худуд ал-'Алем. Табл. 38б; Hudud al-'Alam. P. 162-163.

${ }^{65}$ Коковиов П. К. Еврейско-хазарская переписка в Х в. Л., 1932. С. 92.

${ }^{66}$ Худуд ал-'Алем. С. 29.

${ }^{67}$ Григорьев В. В. Волжские болгары // Россия и Азия. Сборник исследований и статей по истории, этнографии и географии. СПб., 1876. С. 91.

${ }^{68}$ Греков Б. Д., Калинин Н. Ф. Булгарское государство до монгольского завоевания // Материалы по истории Татарии. Вып. І. Казань, 1948. С. 107.

${ }_{69}^{6}$ Фахрутдинов Р. Г. Очерки по истории Волжской Булгарии. М., 1984. С. 15.

${ }^{70}$ Измайлов И. Л. Становление Волжской Булгарии: от племени к государству // Studia Slavica et Balcanica Petropolitana. 2012. № 2 (12). Июль-декабрь. С. 220.

${ }_{71}$ Лаврентьевская летопись // ПСРЛ. Т. 1. Л., 1926-1928. С. 58.

72 Лаврентьевская летопись. С. 58.

73 Лаврентьевская летопись. С. 58-59.

74 Лаврентьевская летопись. С. 60.

75 Зимин А. А. Память и похвала Иакова Мниха и Житие князя Владимира... С. 71.

${ }^{76}$ Плетнева С. А. Половцы. М., 1990. С. 23.

77 Толочко П. П. Кочевые народы степей и Киевская Русь. К., 1999. С. 80.

${ }^{78}$ Новосельцев А. П. Хазарское государство и его роль в истории Восточной Европы и Кавказа. M., 1990. C. 227.

${ }_{79}$ Срезневский И. И. Материалы для словаря древнерусского языка. Т. 3. СПб., 1912. С. 337-338.

${ }^{80}$ Ипатьевская летопись. С. 429.

${ }^{81}$ Измайлов И. Л. Становление Волжской Булгарии: от племени к государству. С. 220.

82 Лаврентьевская летопись. С. 60.

${ }^{83}$ Гагин И. А. В. Н. Татищев и российская историография о походе князя Владимира на болгар в 985 г. // Вестник Санкт-Петербургского университета. Сер. 2. 2009. Вып. 1. С. 50.

${ }^{84}$ де ля Примод. История черноморской торговли в средние века / Изд. В. Шостаком. Ч. 1. Одесca, 1850. C. 96.

${ }^{85}$ Карамзин Н. М. История государства Российского. Кн. 2. T. V-VIII. М., 1992. С. 34, прим. 61.

${ }^{86}$ Тунманн. Крымское ханство. Симферополь, 1991. С. 70. 